\title{
Influence of bonding condition between layers on overlay design of flexible pavements
}

\section{Influência da condição de aderência entre camadas no dimensionamento de reforço de pavimentos asfálticos}

\author{
Marcos Lamha Rocha', Geraldo Luciano de Oliveira Marques², Rafael Cerqueira Silva ${ }^{3}$, \\ Laura Maria Goretti Motta ${ }^{4}$ \\ 1Universidade Federal do Rio de Janeiro, Rio de Janeiro - Brasil, marcosIr94@gmail.com \\ ${ }^{2}$ Universidade Federal de Juiz de Fora, Minas Gerais - Brasil, geraldo.marques@ufjf.edu.br \\ ${ }^{3}$ Universidade de Brasília, Distrito Federal - Brasil, rafael.silva@unb.br \\ ${ }^{4}$ Universidade Federal do Rio de Janeiro, Rio de Janeiro - Brasil, laura@coc.ufrj.br
}

\section{Recebido:}

9 de julho de 2020

Aceito para publicação:

16 de outubro de 2020

Publicado:

24 de agosto de 2021

Editor de área:

Jorge Barbosa Soares

\section{Keywords:}

Adhesion.

Reinforcement.

MeDiNa.

Flexible pavement.

\section{Palavras-chave:}

Aderência.

Reforço.

MeDiNa.

Pavimento flexíveis.

DOI:10.14295/transportes.v29i2.2419

\begin{abstract}
The interface bonding conditions between the pavement layers is one of the main factors influencing the performance of the pavement structure. The present paper analyzes the effects of the interface conditions between the layers on the process of overlay design in flexible pavements. The data were collected by deflection testing using Falling Weight Deflectometer (FWD) and by drilling cores. Simulations were performed in the software BackMeDiNa, MeDiNa and AEMC for three different conditions of interface between the layers. The data of backcalculated moduli, overlay thicknesses, cracked area and fatigue damage were compared under different bonding conditions. In most of the simulations, backcalculated moduli in the de-bonding condition were higher than ones in the full-bonding between the layers. For the overlay design, the modular sets obtained from the different interface conditions led a slight difference in the thickness of the new asphalt layer (reinforcement), but with higher percentages of cracked area for the structures with full-bonding condition. In the analysis of the fatigue damage, the results showed that the damage obtained with the full-bonding layers was higher than that one obtained with de-bonding interfaces and the bonding between the surface and base layers.
\end{abstract}

\section{RESUMO}

As condições de aderência entre as camadas do pavimento é um dos principais fatores que influenciam no desempenho da estrutura. O presente artigo analisa os efeitos da condição (aderida ou não) das interfaces das camadas no dimensionamento da camada de reforço em pavimentos asfálticos. Os dados utilizados no projeto foram obtidos por meio de ensaios deflectométricos com uso do Falling Weight Deflectometer (FWD) e por abertura de poços de sondagem. Foram realizadas simulações nos softwares BackMeDiNa, MeDiNa e AEMC para três condições distintas de aderência entre as camadas. Comparou-se os valores de módulos retroanalisados, espessuras e análise de área trincada no dimensionamento da camada de reforço e dano médio à fadiga resultante das diferentes condições de interface. Na maioria das simulações, foram obtidos maiores valores de módulos retroanalisados pela condição de não aderência entre as camadas. Para o dimensionamento da camada de reforço, os conjuntos modulares obtidos das diferentes condições de interface resultaram em uma pequena diferença na espessura da camada, mas com porcentagens de área trincada maior para a condição de aderência total. Na análise do dano à fadiga, os resultados mostraram que os danos obtidos com todas as camadas aderidas foram maiores do que os obtidos com as camadas não aderidas e aderência apenas entre as camadas de revestimento e base. 


\section{INTRODUCTION}

Asphalt pavement is a multilayer system structure composed of various layers with different materials and thicknesses, designed to bear the effects of loads and environmental conditions. The current mechanistic methods of pavement design are based on stress and strains analysis.

A poorly designed pavement can lead to early failures and shortened life expectancy. Therefore, it is paramount importance that a pavement design to take into account all the intervening factors in order to able to withstand the external effects. Among the pavement distress, it can be cited: rutting, fatigue cracking, thermal cracking and slippage cracking.

Slippage failure is one of the distress that can occur at pavement layers due weak bonding condition between the layers, mainly between the asphalt layers. That failure often happens on some locations of the pavement, such as the breaking or turning movement at intersection (Hariyadi and Utami, 2015).

The bonding condition between the layers is important to ensure the layers work as a composite structure in order to support the traffic and environmental loading, and if that condition does not happen, premature failures and deformations may occur. Nevertheless, the guarantee of total or partial bond may not be obtained due to the differences in characteristics between the layers.

Flexible pavements are typically considered as an elastic multilayer and most of the pavement design methods assume only two interface conditions: full-bond (i.e. no slipping) or nobond (i.e. slipping). However, they are the extreme conditions and are not realistic in the field. In practice, the pavement layers are neither fully bonded nor fully no-bonded. For computational analysis, the use of one or the other condition has an impact on the stress and strain distribution, and depending on the calculation method and design criteria, it may impact the thickness of the layers.

In a conventional flexible pavement with granular base and subbase layers, or even the semirigid pavements (stabilized soil layers or gravel treated with cement), the bonding conditions between layers are so diverse that there is no guarantee of total bond. However, in pavement constructions, the bonding between asphalt layers (mainly if they are placed almost simultaneously) is facilitated by the compatibility between them. Numerically, the bonding condition between asphalt layers (which in field is possible and should be encouraged) and nobond between the asphalt and granular layers and between the granular layers is accepted as a good representation of the "ideal" situation of a pavement. Considering that the shear stress from the loads are concentrated in the surface, it is important to ensure the bond between asphalt layers.

This paper aims to analyze the impact of the bonding condition on the overlay design by using the MeDiNa software. Simulations were performed in BackMeDiNa, MeDiNa and AEMC software for three interface conditions: full-bond; full no-bond; and full-bond only between the base and surface layers. In addition, the impact of interface conditions on the percentage of cracked area was evaluated by using data from monitored sections. 


\section{BACKGROUND}

Inadequate bonding between the pavement layers can reduce the life of the road and affect its performance. Slippage failures between layers (mainly the asphalt layers) have been heavily studied due to poor bond conditions in pavements. The most common failures associated with the poor bonding of the pavement are: slippage cracks and deformation on the surface layer. Romanoschi and Metcalf (2001) observed that many of the failures related to the bonding conditions were caused by the non-consideration of the horizontal stresses, since many programs only considered the vertical stresses as critical.

According to Uzan et al. (1978) the stress distribution in the pavement is strongly influenced by the interface condition between the layers. This occurs due to the layer placement method, which is done in steps, enabling poor bonding conditions between the layers (Hu and Walubita, 2010).

Romanoschi and Metcalf (2001) found that all parameters involved in the bonding conditions between the surface asphalt layers are temperature-dependent. In practice, to reach the maximum bonding between layers, it is important to understand the factors of influence the interface behavior, namely: aggregate size, type of compaction, asphalt content, stress conditions and materials (Jaskula, 2014).

Some studies have tried to model the effect of the interface condition on the pavement structure. Torquato Silva et al. (2018) modeled the interface between surface and base layers by using Mohr-Coulomb constitutive model, Goodmans' Law and by using the Finite Element method. Also, Scherer (2018) developed a test to determinate the bond between the surface and graded gravel base layers based upon the interface shear. The author analyzed shear strength and shear relaxation modulus, and found that the temperature, normal stress and type of treatment applied affect the bond conditions.

Foncesa (2015) introduces several test that can be performed to evaluate the bond between asphalt layers and the use of geosynthetics, emphasizing the rate of take coat with different asphalt emulsions. The author using computational analysis concluded that the stress distribution and the structure behavior are adversely affected when there are decreases in the bond rates between asphalt layers.

Torquato e Silva et al. (2019) proposed an alternative method for the consideration of bonding between pavement layers. In their proposed model, they linearized the dependence on the stress, which makes it possible to use more realistically in the pavement design. For such consideration, it is necessary to input interface properties and temperature data.

Other studies have focused on the analysis of the bond condition in the pavement performance. Santos et al. (2019) used the ABAQUS software and found that the interface condition affects more fatigue performance than rutting and that in both distress, the consideration of full-bond between layers led to the prediction of better structure performance. Scherer et al. (2019) analyzed the influence of bonding between surface and base layers in terms of fatigue damage and they concluded that when these layers are no-bonding the damage was higher than when full-bond. As a result, the aforementioned studies found that the nobonding between the layers may require a thicker structure than that designed as layers fullbond for the same traffic. These studies evaluated the bonding condition by using moduli from tables or laboratory tests.

Tschegg et al. (1995) used an analogy between the bearing capacity of a beam, confirming 
that the deflections of the beam with well bond interfaces were nine times lower than ones with no-bond. Bueno (2016) by using deflectometer tests and backcalculations process, compared the results of backcalculated moduli for the full-bond and no-bond conditions between all layers with the use of BakFAA software. The author noted that the backcalculated moduli from fullbond structures were significantly lower than those obtained from the no-bond structures.

Lopes (2019) used the BackMeDiNa software and also observed the same trend of the increase of the backcalculated moduli in the full no-bond conditions between the layers. The pavement life was analyzed by using MeDiNa software and she found a design life decrease when in the backcalculation process, the full-bond condition between layers was considered.

Mousa et al. (2016) evaluated the interface conditions based on FWD deflections measurement. The authors used different bond levels and they found that the interface condition has an important influence on the backcalculation accuracy, with the effect of condition more significant for the base layer than for the asphalt layer.

There are also other studies that have focused on the bonding condition and non-destructive evaluation, such as Metha (2007) which used deflectometer data to identify bonding failures between surface and base layers, and Nguyen (2016) which used deflections data from Germany, and found that it is more feasible to consider deflections out of the stress bulb to predict the bonding conditions.

American and European pavement design software usually consider the layer as full-bonded. Nevertheless, under realistic conditions this bonding assumption is unknown, ranging from full-bond to no-bond, depending on the properties of the material and on the construction quality (Kruntcheva et al., 2005).

However, it is always necessary to consider the calibration analyses in each software used. Overall, the importance of stress-strain analyses must be considered as a numeric effect, which the software developer established in order to decide the calculation process, but all the decisions taken afterwards will be compared with the field data when calibrating the software. Hence, this step is "intermediate", and each set of hypotheses assumed will eventually yield a different calibration.

This paper aims to analyze the effect of bonding condition between layers in the backcalculation process and its influence on the overlay design of flexible pavements, since the backcalculated moduli are used in the design calculations. Regarding the backcalculation, the designer's decision must be ahead of the process, inclusive to mark the moduli obtained for each layer. The same deflectometer basin can be analyzed in several ways, for instance, fixing the module of one layer and varying those of the other layers. Therefore, the user's experience during the backcalculation process is essential.

\section{MATERIALS AND METHODS}

\subsection{Pavement Section}

The field and laboratory investigations were developed on the flexible pavement of the ring road of the Federal University of Juiz de Fora (UFJF, acronym in Portuguese). Its construction dates back to the 1960s and since them, only one rehabilitation has been carried out, in 1991, with an overlay of $4 \mathrm{~cm}$.

Along 2,140m of section extension, 107 stations were mapped with $20 \mathrm{~m}$ distance between them (Figure 1). Nevertheless, since there were elements of traffic calming system, these were 
not included during the study, which resulted in 98 stations. It should be noted that the average operating speed of the section is around $45 \mathrm{~km} / \mathrm{h}$.

The analyzed structure is composed of a pavement with one asphalt layer (made up of two layers - considered as only one layer due the age of both) overlaid on a base, subbase, improved subgrade and subgrade layers. The thickness, the type of material and the Poisson's coefficients (according to Balbo (2007
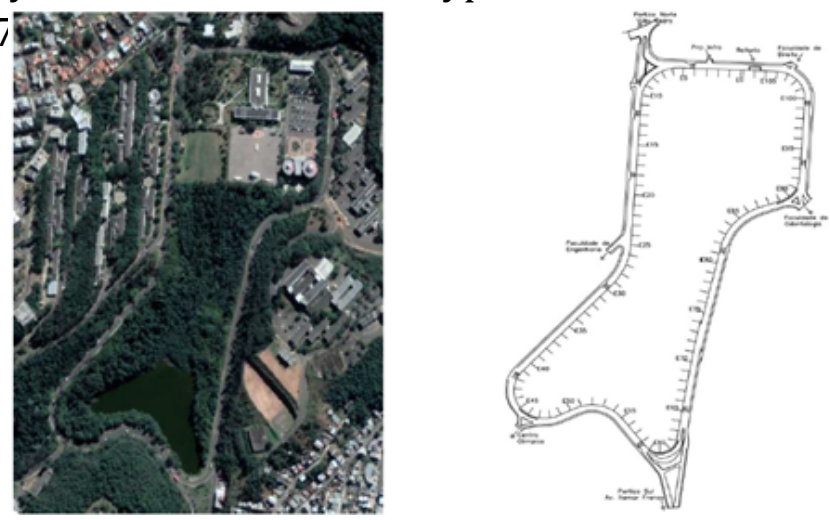

Figure 1. Schematic representation of the UFJF Ring Road

Table 1 - Structure of the pavement

\begin{tabular}{lllll}
\hline Layer & Material & Type of Material & Thickness (cm) & $\mathbf{v}$ \\
\hline $\mathbf{0 1}$ & Asphalt concrete & - & 8 & 0.30 \\
$\mathbf{0 2}$ & Base & Pink silty sand & 10 & 0.35 \\
$\mathbf{0 3}$ & Subbase & Beige silty sand & 20 & 0.35 \\
$\mathbf{0 4}$ & Improved Subgrade & Brown clay & 40 & 0.45 \\
$\mathbf{0 5}$ & Subgrade & Clay-silt orange with fine sand (micaceous) & $\infty$ & 0.45 \\
\hline
\end{tabular}

\subsection{Deflectometer Measurements}

The FWD 8833 device from the Swedish manufacturer Konsult \& Utveckling AB (KUAB) was used for the deflectometer measurements by using nine geophones (Linear Variable Differential Transformers - LVDTs). These LVDTs are placed in the center of load plate and at distances of $20 \mathrm{~cm}, 30 \mathrm{~cm}, 45 \mathrm{~cm}, 60 \mathrm{~cm}, 90 \mathrm{~cm}, 120 \mathrm{~cm}, 150 \mathrm{~cm}$ and $180 \mathrm{~cm}$.

In Brazil, the measurements of failures cracking are carried out by sampling, and only a percentage of the pavement area is considered. In this paper, the surface condition measurement was used for the qualification and quantification of the existing distress on the pavement. This procedure (called Contiuous Computerized Visual Survey - LVCI) by using the Scanning Method (Silva et al. 2018) is under standardization (DNIT/IPR). The International Roughness Index (IRI) was calculated by using a device suspended on the bumper (with no contact with the pavement surface) that uses the laser light wave method for the measurement data. The device has five laser moduli installed on a bat attached to the front of the vehicle.

A borehole of $80 \times 80 \mathrm{~cm}$ was drilled in the pavement of the UFJF Ring Road at the station 40 in order to collect materials to test and determine the layer thicknesses. The material samples were tested in the laboratory of Fundação Centro Tecnológico of Juiz de Fora (FCT-JF) for the characterization of the materials. 


\subsection{Backcalculation}

As a first step in the backcalculation process, the section was divided into homogeneous segments in order to extend the validity of structural and traffic data measured at a given point to the length of a road section. The procedure was the one indicated by AASHTO (1993), which makes use of accumulated differences and uses measured maximum deflections as parameter, yielding eight homogenous segments. BackMeDiNa software was used to backcalculation the 98 deflection basins. The software calculates the difference between measured and calculated deflections of each geophone, taken them into account in the calculation of the error, which is obtained by the Root Mean Square (RMS). Afterwards, the moduli of homogeneous segments were adopted as the average of the backcalculated moduli of their deflection basins.

BackMeDiNa software provides two interface conditions between the layers: full-bond, which the layers are considered fully bonded, and full no-bond, which the layers have full slip between them. For this paper, three interface conditions were studied in the backcalculation process: full no-bond between all layers (C1); full-bond between all layers (C2); and full-bond only between the surface and base layers (C3).

\subsection{Overlay Design}

The following step was to evaluate the effect of the bonding condition used in the backcalculation process on the overlay design. The mechanistic-empirical pavement design software called "National Pavement Design Method (MeDiNa in the Portuguese acronym)" was used, which is part of the same package of BackMeDiNa. The modular sets (backcalculated moduli of each segment) yield in different interface conditions between the layers were input into the design software, whereby the same bonding conditions of the backcalculation were used. It should be noted that in MeDiNa software the pre-existing surface layer and the new one (reinforcement) are considered full no-bond and that condition cannot be altered.

However, it is necessary to point out that the criteria of the backcalculation and design process must be equivalent, and therefore in the MeDiNa and BackMeDiNa, interface conditions between layers different from those for which the software was calibrated (full no-bond) should not be used. That may have an impact on the design overlay. The bonding criteria adopted were chosen due to the fact that are in the favor of safety, since a complete bonding between the layers may not occur during the placing, and mainly because they show higher compatibility in the results of the pavement stress state.

In order to use MeDiNa software, the user must input some additional data of the pre-existing asphalt layer, such as the cracked area and IRI. The asphalt mixture used as overlay was designed by Superpave Method by using one binder usually utilized in the region (CAP 50/70). The design was performed by Neumann (2018) in the Pavement Laboratory of UFJF with resilient module of $5,963 \mathrm{MPa}$ and fatigue constants $\mathrm{k} 1$ and $\mathrm{k} 2$ equal to $7.4 \times 10^{\wedge}-1$ e $\mathrm{k} 2$ and -3.3104 , respectively $\left(\mathrm{N}=\mathrm{k} 1 \varepsilon^{\mathrm{k} 2}\right)$.

Subsequently, the traffic data were input, such as: type of road, average daily traffic (VMD), vehicle factor (FV), percentage of traffic in the project line, traffic growth rate and the design period. The VMD value was determined for the analysis's first year (2020) as 9,300 vehicles, considering $83 \%$ passenger cars, $15 \%$ urban buses and $2 \%$ trucks, and an estimated $50 \%$ of vehicles in the project line, leading to a number $N$ (or ESAL) equal to $1,05 \times 10^{\wedge} 7$ in the design period (10 years). 


\subsection{Mechanistic Prediction of Pavement Performance (Fatigue Damage)}

Based on the results obtained in the computational simulations (backcalculated moduli), the influence of interface condition between the layer on the fatigue damage for each condition was evaluated. Since in the MeDiNa software the full-bond condition between the new and pre-existing asphalt layer is not available, three more interfaces conditions (C4, C5 and C6) were evaluated by using a linear elastic analysis software (AEMC), where the bond between the

asphalt layers was considered. Table 2 summarizes the interface conditions, where NB represents "no-bond" and FB represents "full bond" in relation the layer below.

Table 2 - Interface conditions of the analyzed structures

\begin{tabular}{lllllll}
\hline Condition & $\begin{array}{l}\text { New asphalt layer } \\
\text { (Reinforcement) }\end{array}$ & $\begin{array}{l}\text { Pre-existing } \\
\text { asphalt layer }\end{array}$ & Base & Subbase & Improved Subgrade & Subgrade \\
\hline C1 & NB* & NB & NB & NB & NB & - \\
C2 & NB* $^{*}$ & FB & FB & FB & FB & - \\
C3 & NB* & FB & NB & NB & NB & - \\
C4 & FB & NB & NB & NB & NB & - \\
C5 & FB & FB & FB & FB & FB & - \\
C6 & FB & FB & NB & NB & NB & - \\
\hline *only in the MeDiNa software & & & &
\end{tabular}

The fatigue performance of the pavement can be expressed as a function of the permissible stress ( $\mathrm{N}_{\mathrm{fad}}$ ), which is equivalent to the number of cycles that a load can be applied until the structure's performance is compromised. The determination of $\mathrm{N}_{\text {fad }}$ is carried out by experimental fatigue models, which are the result of statistical analysis of laboratory tests, taking the principal strain of tension into account $\left(\varepsilon_{t}\right)$.

Using the expected traffic $(\mathrm{N})$ for a design period and $\mathrm{N}_{\text {fad }}$ it is possible to calculate the unit damage $\left(D_{u}\right)$ and the average damage (Daverage) to the expected fatigue for the pavement over time (Nascimento, 2015). MeDiNa software was developed by relating fatigue damage to the cracked area using a transfer function. However, this function was considering different bonding conditions from those analyzed in this paper, hence the decision to study the average damage instead of only the cracked area in the software.

The unit damage is obtained by the relationship between $\mathrm{N}$ and $\mathrm{N}_{\mathrm{fad}}$ by Miner's Law. For a given number of points distributed in the surface layer, the average damage to the pavement can be obtained from the unit damage as a function of time. In order to determinate $\mathrm{N}_{\mathrm{fad}}$, AEMC software was used (considering the bonding conditions of Table 2) to calculate the tension strains in a 110-point mesh in the asphalt layer as presented by Nascimento (2015), adopting at first an overlay of $5 \mathrm{~cm}$ and then $10 \mathrm{~cm}$. The $\mathrm{N}_{\mathrm{fad}}$ is calculated by using the material fatigue curve obtained from laboratory tests, expressed by the constants k1 and k2. Equations 1 and 2 show the formulae of Du e $\mathrm{N}_{\text {fad. }}$.

$$
\begin{gathered}
N_{f a d}=k 1 \times \varepsilon_{t}{ }^{-k 2} \\
D_{u}=\frac{N}{N_{f a d}}
\end{gathered}
$$

In an update of the MeDiNa transfer function, Fritzen et al. (2019), considered the use of the average damage $\left(D_{\text {average }}\right)$. Unlike the previous functions, the $D_{\text {average }}$ is calculated in a mesh of 20 points of the surface layer (10 on the surface and 10 on the bottom) and is obtained by dividing an application of the standard load axle by the permissible number of load axle 
application, expressed by Equation 3.

$$
D_{\text {average }}=\frac{1}{20} \sum\left(\frac{1}{N_{\text {fad }}}\right)
$$

\section{RESULTS}

\subsection{Backcalculated moduli (BACKMeDina)}

The deflection basins of eight homogeneous segments were backcalculated until an error (i.e. difference between the calculated and measured deflections) lower than $10 \mu \mathrm{m}$ for the three bonding conditions (C1, C2 and C3). Figure 2 shows the backcalculated moduli for the five layers.
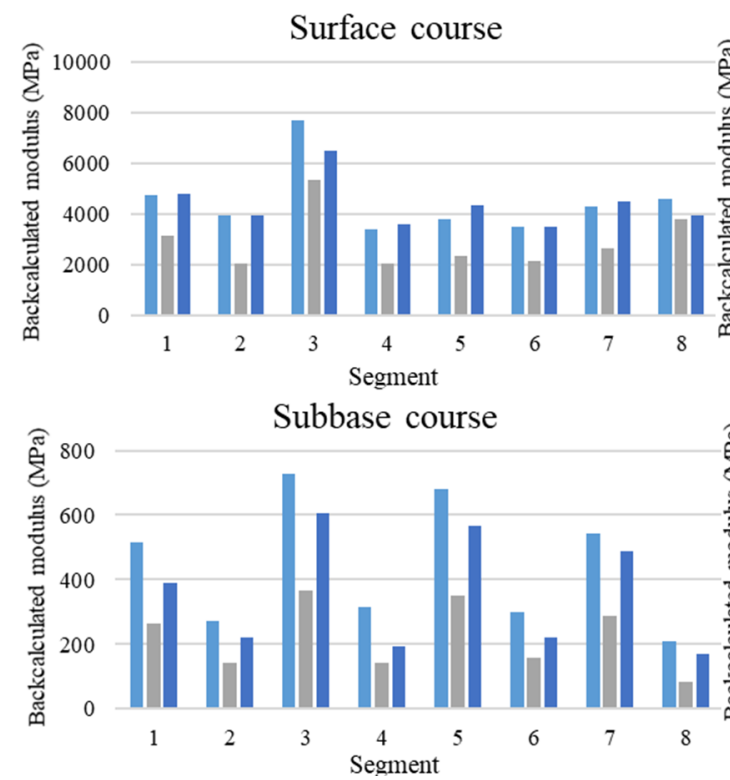

Subgrade course

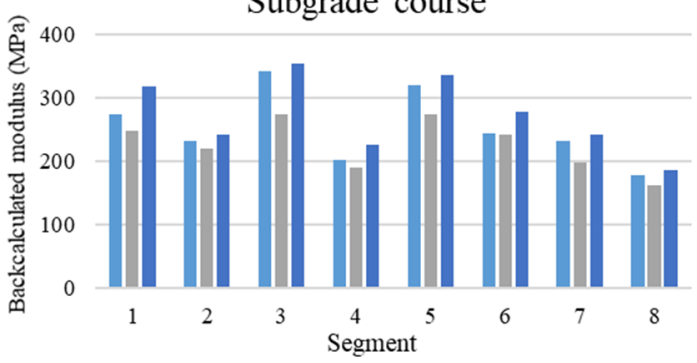

Base course

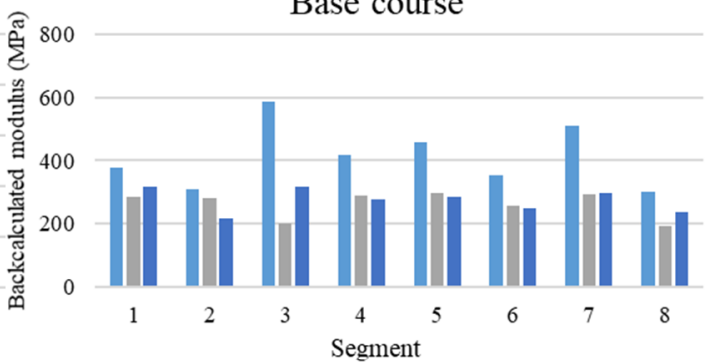

Improved Subgrade course

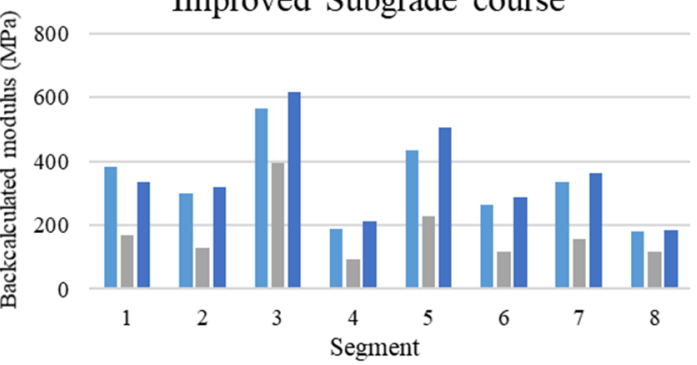

C1 - no-bond between all layers

- C2 - full-bond between all layers

- C3 - full-bond only between surface and base layers

Figure 2. Backcalculated moduli for the three interface conditions

As can be seen from Figure 2 the different interface conditions have yielded significantly different backcalculated moduli. Overall, the moduli of full-bond condition were lower than ones of other conditions. The results were expected, since the consideration of the no-bond condition between the layers leads to higher strains in the structures, resulting layers stiffer in the backcalculation process in order to produce de same basin as a structure with bonded layers.

By comparing conditions $\mathrm{C} 1$ and $\mathrm{C} 2$, it can be seen that the moduli of the first one were substantially higher for all layers. The percentage differences between the moduli for those two conditions of the base and improved subgrade layers were the highest (on average 50\%). The surface and base layers showed the lowest differences, with 35\% reductions for the second condition. For the subgrade, lower variations were noted (under $20 \%$ ). 
In comparison with $\mathrm{C} 1$ and $\mathrm{C} 3$ conditions (where only the bonding condition between the surface and base layers was changed), the variations of moduli were slight. For the surface, improved subgrade and subgrade layers the differences in the backcalculated moduli were minimal, under $15 \%$. However, for the base and subbase layers, the differences were significant, over $30 \%$ percentage variation.

To be able to comprehend these differences, a consideration must be made of process of numerical calculation versus the real condition of the interface between layers. Thus, the concept of numerical neutral axis (NA) and the representation of the bonding condition between layers are used in this paper. The difference in results can be explained by considering that if the surface and layers are no-bonded, each layer works "independently", with its own neutral axis, and the bottom of surface layer (under the NA) will be subject to tension and the base layer only to compression. In contrast, if the layers are bonded, they work "monolithical", with only one neutral axis. In this case, if the NA is laid in the surface, it is subject to compression and tension, but the base layer is not capable of performing the tension (thus it not corresponding the numerical consideration). If the NA is laid in the base layer, the asphalt and part of the base layers (up to the neutral axis) will withstand compression and under the NA the tension, different from the real situation.

\subsection{Overlay's Thickness and Expected Cracked Area - MeDiNa}

In order to evaluate the impact of the bonding conditions assumed in the backcalculation process on the overlay design, such modular sets of cases C1, C2 and C3 were inputted into MeDiNa software and run with the same interface conditions. That analysis was performed to study the influence of the adopted criteria of bonding condition on the overlay design. However, in the real situations the interface condition assumed in MeDiNa software should be the same as the one for which the program was calibrated. It is worth pointing out that if the AEMC and BackMeDiNa software the designer is able to change the interface condition between the layers for his own sensitivity analysis, while in the MeDiNa software it is not allowed, since the transfer function included in the program was set with the defined bonding conditions.

Table 3 and Figure 3 summarize the results of thickness and cracked area at the end of design period for the conditions provided by MeDiNa when different backcalculated moduli are inputted. This situation represents the same set of deflections, i.e. structural state.

Table 3 - Thickness and cracked area for different interface conditions

\begin{tabular}{lllllll}
\hline \multirow{2}{*}{ Segment } & \multicolumn{2}{l}{ Thickness $(\mathbf{c m})$} & \multicolumn{4}{l}{ Cracked area (\%) } \\
\cline { 2 - 7 } & C1 & C2 & C3 & C1 & C2 & C3 \\
\hline $\mathbf{1}$ & 5.00 & 5.00 & 5.00 & 24.58 & 28.51 & 23.17 \\
$\mathbf{2}$ & 10.70 & 11.30 & 10.70 & 29.31 & 28.15 & 29.83 \\
$\mathbf{3}$ & 5.00 & 5.00 & 5.00 & 8.11 & 19.25 & 12.90 \\
$\mathbf{4}$ & 11.30 & 11.30 & 11.30 & 29.73 & 29.93 & 29.76 \\
$\mathbf{5}$ & 5.00 & 5.00 & 5.00 & 24.35 & 29.51 & 23.33 \\
$\mathbf{6}$ & 10.70 & 11.00 & 10.70 & 29.70 & 29.19 & 29.93 \\
$\mathbf{7}$ & 5.00 & 5.00 & 5.00 & 25.05 & 28.51 & 24.97 \\
$\mathbf{8}$ & 11.90 & 11.90 & 11.90 & 29.14 & 29.46 & 29.55 \\
\hline
\end{tabular}

According to Table 3 and Fig. 3 the interface conditions between the layers have less effect on the overlay design than on the backcalculation process. By comparing the conditions inter- 
face, in most segments the expected thicknesses were the same for the three conditions, suggesting that there was a "compensation" between the moduli of the layers. This is more evident in the percentage of cracked areas. It should be noted that the lowest overlay's thickness expected $(5 \mathrm{~cm}$ ) leads to a total asphalt layer thickness of $13 \mathrm{~cm}$, which already defines a thick surface for the Brazilian pavements.

For the segments in which there was variation in the overlay thickness, the second condition (C2) led to higher thicknesses than conditions C1 and C3. It can be seen as a consequence of the different that were observed, since the full-bond condition yielded lower moduli.

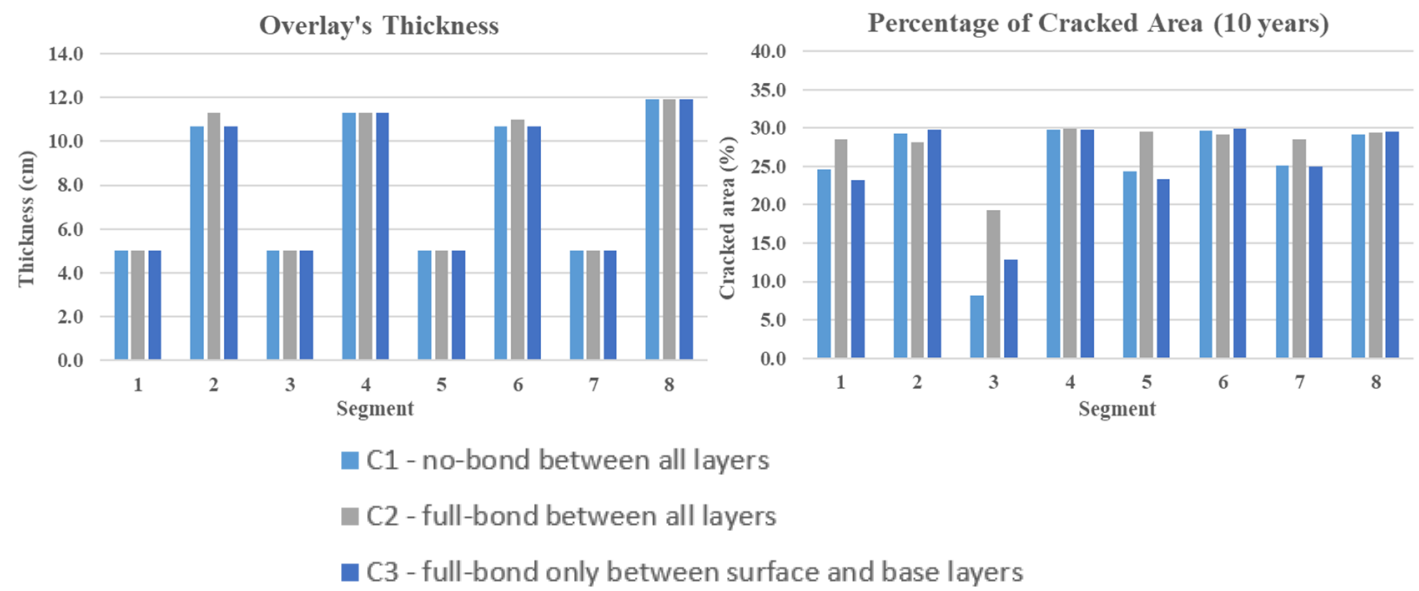

Figure 3. Thickness and cracked area for different interface conditions

With regard to the percentage of cracked area (CA) at the design period, the CA for the fullbond condition (C2) were higher for the structures with the same thicknesses. Similar to the analysis of thicknesses, the reason is that the backcalculation process for the second condition yielded lower modular sets. The variation in the bonding condition between surface and base layers resulted in slight alterations in the CA, with similar values between them. However, the segment 3 showed a significant change in the cracked area.

The results are according to other studies, such as Lopes (2019), who used the same software, but only C1 and C3 conditions were studied. The author evaluated the pavement life analysis, i.e., the period which the pavement reached 30\% of CA, and founded that in the no-bonding condition the structure has a life-span in relation to the structures designed considering full bond between the layers.

\subsection{Fatigue Damage Expected}

\subsubsection{Overlay Thickness of $5 \mathrm{~cm}$}

Based on the backcalculated moduli for the different bonding conditions, those were inputted into AEMC software in order to evaluate the fatigue damage over time, with the inclusion of the bonding conditions of the new and pre-existing surface interface. Figure 4 shows the average damage fatigue over time, where each curve depicts the behavior of the damage in the structures with the interface conditions listed in Table 2.

According to Figure 4, the curves of all segments tend to exhibit an asymptotic behavior. This type of evaluation of the fatigue damage over time indicates a sharp rise at the beginning of the pavement life (around 5 and 10 months), proceeding with a lower rise rate until the design period. This sharp initial rise rate can be seen as the range of damage close to the limit in 
the first months. Nevertheless, that does not mean that the pavement is failed, and for such evaluation it is necessary to investigate the cracking by calibrations obtained from the evaluation of the sections. It should be pointed out that the aim of that paper is to highlight the differences in interface conditions and that in the end, the numerical analysis alternatives (mechanistic aspect) are completed with the calibration (empirical aspect), which includes the "consequences" of the bonding conditions considered.

The curves in relation to the bonding conditions showed similar behavior. Among the six interface conditions, the second one (C2) had the highest average damage for all segments. In view of this, the consideration of full-bond between the layers in the backcalculation process leads to a decrease in the useful life of the structure, as shown by the analyses of the cracked area from MeDiNa. The curves of interface conditions C1 and C3 showed analogous behavior. The two curves, depicted by the green and gray solid lines, tend to be the same pattern throughout the design period, overlapping for most segments. 

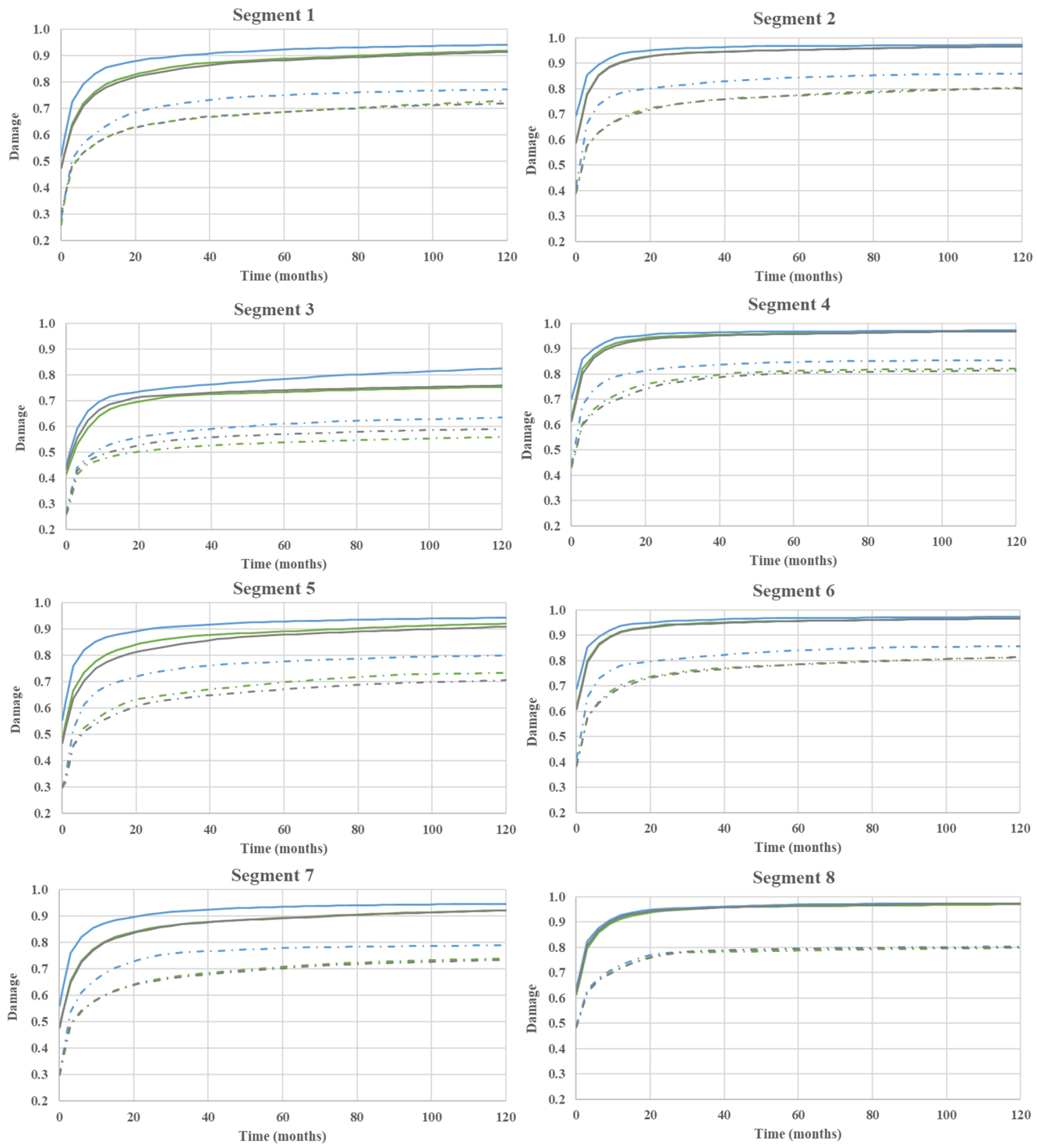

- $\mathrm{Cl}$ - no-bond between all layers

$\mathrm{C}_{2}$ - full-bond between all layers

C 3 - full bond only between surface and base layers

$-\cdot$ - C4 - full-bond between new and pre-existing asphalt layers and other layers no-bond
$-\cdots-$ C5 - full-bond between new and pre-existing asphalt layers and other layers full-bond

- - - C6 - full-bond between new and pre-existing asphalt and base e surface layers and other layers full-bond

Figure 4. Average fatigue damage over time for different interface conditions (Overlay $-5 \mathrm{~cm}$ )

The highest difference in behavior between the trend curves was the bonding conditions between the pre-existing and new asphalt layers. For all these cases (C4, C5 and C6) there was a significant life span when compared to conditions C1, C2 and C3. This differences can be explained by the fact that for the bonding condition between the two asphalt layers, they work "monolithical" with one sole neutral axis, varying the maximum strains in magnitude and position. However, it is difficult to guarantee that the new asphalt layer (reinforcement) is totally bonded to the cracked pre-existing layer and that it continues to have the same fatigue strength. Therefore, the no-bond consideration in this case is justified.

In order to better understand the effect of different bonding conditions on the fatigue, the 
time required to reach the damage fatigue values of 0.80 and 0.90 and the average damage fatigue were compared by using the curves of Figure 4 and Equation 3, respectively. Table 4 summarizes the values found for these parameters for the six conditions.

It is observed from the Table 4 that for the majority of the segments the damage of 0.80 and 0.90 occur in the first months, which can be justified by the thickness of overlay $(5 \mathrm{~cm})$. In the comparison between the segments, the segment 3 had a better behavior, which for almost all the interface conditions the fatigue damage occurred after 120 months. On the other hand, segments 4 and 6 reached the damage of 0.80 and 0.90 at low ages.

Table 4 - Time required to reach the damage fatigue values of 0.80 and 0.90 and average damage fatigue for different bonding conditions (Overlay $-5 \mathrm{~cm}$ )

\begin{tabular}{|c|c|c|c|c|c|c|c|c|c|}
\hline Condition & Propertie & Seg1 & Seg2 & Seg3 & Seg4 & Seg5 & Seg6 & Seg7 & Seg8 \\
\hline & D@80 (months) & 13.5 & 4 & $>120$ & 2 & 12 & 3 & 12 & 4 \\
\hline \multirow[t]{3}{*}{ C1 } & D@90 (months) & 81 & 11 & $>120$ & 9 & 75 & 9 & 70 & 10.3 \\
\hline & Daverage & $1.5 \mathrm{E}-03$ & $3.0 \mathrm{E}-03$ & 5.7E-04 & $3.6 \mathrm{E}-03$ & $1.5 \mathrm{E}-03$ & $3.3 \mathrm{E}-03$ & $1.6 \mathrm{E}-03$ & 3.4E-03 \\
\hline & D@80 (months) & 7 & 2 & 78 & 1.5 & 4.5 & 2.5 & 5 & 2.2 \\
\hline \multirow[t]{3}{*}{$\mathrm{C} 2$} & D@90 (months) & 33 & 7 & $>120$ & 6 & 24 & 6.5 & 21 & 8 \\
\hline & Daverage & $1.9 \mathrm{E}-03$ & 4.2E-03 & $1.0 \mathrm{E}-03$ & 4.4E-03 & $2.1 \mathrm{E}-03$ & 4.1E-03 & $2.2 \mathrm{E}-03$ & 3.9E-03 \\
\hline & D@80 (months) & 16 & 4.2 & $>120$ & 3 & 17 & 3.5 & 12.2 & 2.8 \\
\hline \multirow[t]{3}{*}{ C3 } & D@90 (months) & 90 & 11.5 & $>120$ & 9.5 & 100 & 10 & 74 & 9 \\
\hline & Daverage & $1.5 \mathrm{E}-03$ & $3.0 \mathrm{E}-03$ & 7.9E-04 & $3.3 \mathrm{E}-03$ & $1.4 \mathrm{E}-03$ & $3.2 \mathrm{E}-03$ & $1.6 \mathrm{E}-03$ & 3.6E-03 \\
\hline & D@80 (months) & $>120$ & 108 & $>120$ & 42 & $>120$ & 84 & $>120$ & $>120$ \\
\hline \multirow[t]{3}{*}{ C4 } & D@90 (months) & $>120$ & $>120$ & $>120$ & $>120$ & $>120$ & $>120$ & $>120$ & $>120$ \\
\hline & Daverage & 3.7E-05 & 7.2E-05 & $2.1 \mathrm{E}-05$ & $8.9 \mathrm{E}-05$ & $2.5 \mathrm{E}-05$ & 7.1E-05 & $3.8 \mathrm{E}-05$ & $1.2 \mathrm{E}-04$ \\
\hline & D@80 (months) & $>120$ & 18 & $>120$ & 15 & 120 & 21 & $>120$ & 84 \\
\hline \multirow[t]{3}{*}{ C5 } & D@90 (months) & $>120$ & $>120$ & $>120$ & $>120$ & $>120$ & $>120$ & $>120$ & $>120$ \\
\hline & Daverage & $3.4 \mathrm{E}-05$ & $7.9 \mathrm{E}-05$ & $2.5 \mathrm{E}-05$ & $9.1 \mathrm{E}-05$ & 2.7E-05 & 7.6E-05 & 3.6E-05 & 1.1E-04 \\
\hline & D@80 (months) & $>120$ & 111 & $>120$ & 54 & $>120$ & 3 & $>120$ & 108 \\
\hline \multirow[t]{2}{*}{ C6 } & D@90 (months) & $>120$ & $>120$ & $>120$ & $>120$ & $>120$ & 9 & $>120$ & $>120$ \\
\hline & Daverage & $4.0 \mathrm{E}-05$ & $7.4 \mathrm{E}-05$ & $2.5 \mathrm{E}-05$ & 8.7E-05 & $2.9 \mathrm{E}-05$ & $3.3 \mathrm{E}-03$ & 4.0E-05 & 1.1E-04 \\
\hline
\end{tabular}

By analyzing the results regarding the bonding conditions, the cases C4, C5 and C6 (i.e. fullbond between asphalt layers) had an increase in its useful life span. When the full-bond between the asphalt layers was considered, regardless of other interfaces, most segments, even the most damaged (i.e. Segments 02, 04, 06 and 08) showed age over 120 months to reach the damage of 0.80 and 0.90 . With regard to the percentage difference between the ages, the structures with no-bond between the asphalt layers had a reduction of $66 \%$ in their useful life span.

With respect to the average damage, the structures in the three last conditions (C4, C5 and C6) had also a significant increase in the final values in relation to the first three conditions (C1, C2 and C3), with the damage varying in the order of $10^{3}$ to $10^{5}$, respectively. When comparing the percentage variation, the full-bond consideration between the asphalt layers resulted in an increase average damage of over $90 \%$.

In the comparison between the first three conditions with each other and between the last three with each other, the same trend can be noticed. The full-bond consideration (C2 and C5) showed a decrease in the useful life, both for the time required to achieve de damage (28\%) and the average damage (19\%) in relation to full no-bond conditions ( $\mathrm{C} 1$ and $\mathrm{C} 4$ ).

Unlike the results shown in Figure 4 and Table 4, other studies, such as Scherer et al. (2019) noted shorter useful life for structures with full no-bond between the interfaces. Nevertheless, it should be noted that the study considered the resilient moduli as constants (using modeled pavements) and varied the interface conditions, which represents only one aspect of the analysis, but it does not mean that the study achieved the same deflection conditions, for instance. In 
this paper, different modular sets that result the same deflection basin were used, which explains the differences in the results for both cases.

Addressing more those differences between the studies, it can be noted that by considering the same moduli and full-bond conditions, the pavement work as a monolithic structure and therefore decreases strains and increases fatigue life. On the other hand, during the backcalculation process, the full no-bond consideration requires that the layers be stiffer so that they can yield the same deflection basin as a structure with layer full-bonded. This modular compensation leads to stiffer structures and higher lifetime.

\subsubsection{Overlay Thickness of $10 \mathrm{~cm}$}

In order to verify the effect of the overlay thickness on the bonding condition, the same fatigue damage analyses were performed, but with a thicker overlay $(10 \mathrm{~cm})$. The average damage over time for the six bonding conditions are presented in Figure 5.

It can be seen that just as it was for the previous conditions, the curve of structures presented a asymptotic behavior. Overall, the fatigue damages were lower for thicker overlay as was expected.

The curves of fatigue damage for the different bond conditions had more similar behavior to each other. For the first three conditions (C1, C2 and C3) the solid lines overlap, demonstrating that the changes in the interface conditions had minimal effect. For the dashed lines (i.e. bonding conditions between asphalt layers) the conditions C4 and C6 presented a similar behavior, while the condition C5 had a shorter fatigue life over time, as well as it was for the structures with overlay of $10 \mathrm{~cm}$.

Table 5 - Time required to reach the average damage fatigue values of 0.80 and 0.90 and average damage fatigue for different bonding conditions (Overlay $-5 \mathrm{~cm}$ )

\begin{tabular}{|c|c|c|c|c|c|c|c|c|c|}
\hline Conditions & Properties & Seg1 & Seg2 & Seg3 & Seg4 & Seg5 & Seg6 & Seg7 & Seg8 \\
\hline & D@80 (months) & 15 & 6 & $>120$ & 4.5 & 17 & 6 & 13.5 & 5 \\
\hline \multirow[t]{3}{*}{ C1 } & D@90 (months) & $>120$ & $>120$ & $>120$ & 69 & $>120$ & $>120$ & $>120$ & $>120$ \\
\hline & Daverage & $1.5 \mathrm{E}-03$ & $2.4 \mathrm{E}-03$ & $7.5 \mathrm{E}-04$ & 2.7E-03 & $1.3 \mathrm{E}-03$ & $2.4 \mathrm{E}-03$ & $1.5 \mathrm{E}-03$ & $3.0 \mathrm{E}-03$ \\
\hline & D@80 (months) & 13 & 4.5 & 27 & 4 & 14 & 4 & 11 & 5 \\
\hline \multirow[t]{3}{*}{ C2 } & D@90 (months) & $>120$ & $>120$ & $>120$ & 54 & $>120$ & $>120$ & $>120$ & $>120$ \\
\hline & Daverage & $1.5 \mathrm{E}-03$ & $2.6 \mathrm{E}-03$ & $1.0 \mathrm{E}-03$ & $2.8 \mathrm{E}-03$ & $1.4 \mathrm{E}-03$ & $2.5 \mathrm{E}-03$ & $1.6 \mathrm{E}-03$ & $3.1 \mathrm{E}-03$ \\
\hline & D@80 (months) & 15 & 6 & 45 & 4.5 & 17 & 6 & 13.5 & 5 \\
\hline \multirow[t]{3}{*}{ C3 } & D@90 (months) & $>120$ & $>120$ & $>120$ & 69 & $>120$ & $>120$ & $>120$ & $>120$ \\
\hline & Daverage & $1.5 \mathrm{E}-03$ & $2.4 \mathrm{E}-03$ & $9.3 \mathrm{E}-04$ & 2.7E-03 & $1.3 \mathrm{E}-03$ & $2.5 \mathrm{E}-03$ & $1.6 \mathrm{E}-03$ & $3.1 \mathrm{E}-03$ \\
\hline & D@80 (months) & $>120$ & $>120$ & $>120$ & $>120$ & $>120$ & $>120$ & $>120$ & $>120$ \\
\hline \multirow[t]{3}{*}{ C4 } & D@90 (months) & $>120$ & $>120$ & $>120$ & $>120$ & $>120$ & $>120$ & $>120$ & $>120$ \\
\hline & Daverage & $2.3 \mathrm{E}-05$ & $4.4 \mathrm{E}-05$ & $1.0 \mathrm{E}-05$ & $6.8 \mathrm{E}-05$ & $2.9 \mathrm{E}-05$ & $5.5 \mathrm{E}-05$ & $2.8 \mathrm{E}-05$ & 4.5E-05 \\
\hline & D@80 (months) & $>120$ & $>120$ & $>120$ & $>120$ & $>120$ & $>120$ & $>120$ & $>120$ \\
\hline \multirow[t]{3}{*}{ C5 } & D@90 (months) & $>120$ & $>120$ & $>120$ & $>120$ & $>120$ & $>120$ & $>120$ & $>120$ \\
\hline & Daverage & $3.4 \mathrm{E}-05$ & $1.1 \mathrm{E}-04$ & $1.2 \mathrm{E}-05$ & $1.2 \mathrm{E}-04$ & $5.3 \mathrm{E}-05$ & $1.1 \mathrm{E}-04$ & $4.8 \mathrm{E}-05$ & 4.9E-05 \\
\hline & D@80 (months) & $>120$ & $>120$ & $>120$ & $>120$ & $>120$ & $>120$ & $>120$ & $>120$ \\
\hline \multirow[t]{2}{*}{ C6 } & D@90 (months) & $>120$ & $>120$ & $>120$ & $>120$ & $>120$ & $>120$ & $>120$ & $>120$ \\
\hline & Daverage & $2.1 \mathrm{E}-05$ & 4.0E-05 & $1.2 \mathrm{E}-05$ & $5.0 \mathrm{E}-05$ & $2.0 \mathrm{E}-05$ & $4.8 \mathrm{E}-05$ & $2.4 \mathrm{E}-05$ & $5.0 \mathrm{E}-05$ \\
\hline
\end{tabular}

Table 5 shows the damage fatigue taken from the fatigue curves for the 0.80 and 0.90 of damage and the average damage calculated by Equation 4. Based on the results, the most segments for the six conditions exhibited damage of 0.80 and 0.90 over the design period (120 months), which illustrates that the thickness of $10 \mathrm{~cm}$ meets most of the cases and supports the design performed in MeDiNa. In the comparison between the interface conditions, the increases of thickness of the overlay reduces the variations in useful life for the different bonding conditions.

The results of the different bonding conditions between the asphalt layers, as well as for the 
structures with overlay of $5 \mathrm{~cm}$, the full-bond structures had higher useful life span. However, in the percentage difference between the increases, a minor value was found, with a $43 \%$ increase in useful life for conditions $\mathrm{C} 4, \mathrm{C} 5$ and $\mathrm{C} 6$ in relation conditions C1, C2 and C3. Regarding to the average damage, there was a decrease of $98 \%$, leading to a similar value to the other structure.
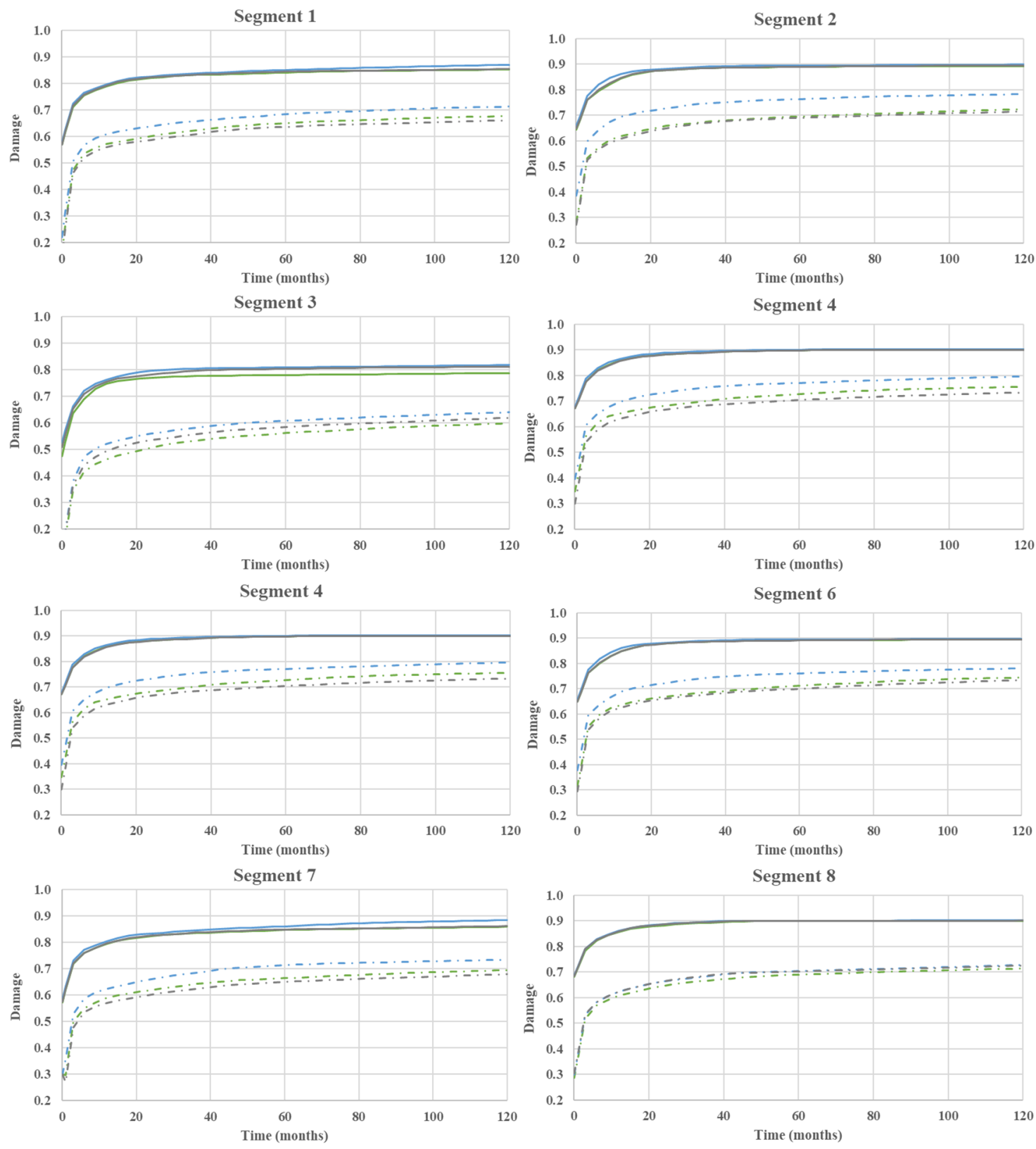

$\mathrm{Cl}$ - no-bond between all layers

C2 - full-bond between all layers

- C 3 - full bond only between surface and base layers

- - - C4 - full-bond between new and pre-existing asphalt layers and other layers no-bond

- - - C5 - full-bond between new and pre-existing asphalt layers and other layers full-bond

- - - C6 - full-bond between new and pre-existing asphalt and base e surface layers and other layers full-bond

Figure 5. Average fatigue damage over time for different interface conditions (Overlay $-10 \mathrm{~cm}$ )

By comparing the full-bond and full no-bond conditions, the differences were lower. The conditions $\mathrm{C} 1$ and $\mathrm{C} 4$ had a useful life variation of $7 \%$ in relation to the $\mathrm{C} 2$ and $\mathrm{C} 5$. For the average damage, the behavior was similar to the previous analyses, i.e., the percentage differences were about $22 \%$. 


\section{CONCLUSIONS}

This paper aimed to analyze the bonding condition at the pavement layer interfaces during the overlay design in flexible pavements. In the backcalculation process, the interface conditions had a significant effect on the final moduli, mainly for the subbase and improved subgrade layers, and a lower impact on the subgrade layer. Slight variations were observed when considering the full-bond condition only between the surface and base layers, with outcomes similar to the full no-bond structures. This is justified by the fact that in the backcalculation method, several sets of moduli can be yield the same deflection basin.

In the design overlay by using MeDiNa software, the results for the bonding conditions studied showed lower differences than those from backcalculation process, due to the modular compensation. Most segments had the same required thickness of overlay for the first three bonding conditions, but with variations of cracked area (CA) over $20 \%$ on average, which may not be negligible. However, it is worth noting that MeDiNa software should be used in the interface conditions in which the program was not calibrated.

Nevertheless, in the analyses by using the average fatigue damage over time, higher effects of the interface conditions were observed. As is customary in the backcalculation process, the backcalculated moduli are considered constants. The outcomes of this case study indicated that the consideration of the bonding condition between the pre-existing and new asphalt layers is what produces the highest impact on the useful life of pavements, highlighting then the importance of the take coat between the layers in order to better the bonding. In practice, if the pre-existing layer is too cracked, it cannot withstand fatigue with the same performance of the new asphalt mixture. This leads to the designer to evaluate the use of an anti-reflective cracking interlayer or even recycling the old asphalt layer.

From the data of fatigue damage, the full-bond consideration between the layers may lead to a lower fatigue life compared to the full no-bond structures with the presence of overlay. Sometimes, the curves of fatigue for intermediate conditions between full-bond and full nobond overlapping in some segments, but in others they were significant different. It should again be pointed out that the interface conditions other than which MeDiNa was calibrated should not be used.

By comparing the thickness of overlay, structures with thicker overlays $(10 \mathrm{~cm})$ showed less sensibility (i.e. percentage differences between useful life) to change of interface conditions than ones with thinner overlays $(5 \mathrm{~cm})$. Such result illustrates that thinner asphalt mixtures are less impacted by bonding conditions.

The designer can judge the study of interface condition during the overlay design of flexible pavements, considering the pavement age and the cracked area of the pre-existing asphalt layer. Besides that, by using BackMeDiNa software it is possible to range the interface conditions between the layer in order to analyze the actual condition of pavement and then choose the best treatment. Nevertheless, the interface conditions in MeDiNa should be obeyed, i.e., during the backcalculation process the interface conditions should not be different from those in which the calibration functions of the design software were calibrated.

\section{REFERENCES}

Balbo, J. T. (2007) Pavimentação Asfáltica: Materiais, Projetos e Restauração. São Paulo: Oficina de Textos. 558p.

Bueno, L.D. (2016) Avaliação Deflectométrica e de Rigidez: Estudo de caso em três trechos monitorados em Santa Maria/RS. 460f. (Master's Thesis). Programa de Pós-Graduação em Engenharia Civil, Universidade Federal de Santa Maria, Centro de Tecnologia. Santa Maria/RS. Disponível em: <https://repositorio.ufsm.br/handle/1/7926 > (acesso em 15/05/2020). 
Hariyadi, E.S. and Utami, R. (2015) Predicting Bonding Condition Between Asphalt Pavement Layers from Measured and Computed Deflection using Layer Moduli Backcalculation. Journal of the Eastern Asia Society for Transportation Studies, v. 11, p.1700-1709. DOI: $10.11175 /$ easts. 11.1700

$\mathrm{Hu}, \mathrm{X}$. and Walubita, L.F. (2010) Effects of layer interfacial bonding conditions on the mechanistic responses in asphalt pavements. Journal of Transportation Engineering, v.137, n.1, p. 28-36. DOI: 10.1061/(ASCE)TE.1943-5436.0000184

Fonseca, L. L. (2015) Avaliação em laboratório do comportamento de camadas asfálticas reforçadas com geossintéticos. 162f. (Master's Thesis). Programa de Geotecnia e Transportes, Universidade Federal de Minas Gerais. Belo Horizonte-MG. Disponível em: < http://hdl.handle.net/1843/BUBD-9ZKK69 > (acesso em 16/05/2020).

Fritzen, M.A.; Franco, F.A.C.P.; Motta, L.M.G. and Ubaldo, M.O. (2019) Atualização da Função de Transferência do Dano de Fadiga para a Área Trincado do Programa MEDINA. Anais do 9o Centro Rodoviário Português. Lisboa, Portugal.

Jaskuła, P. (2014) Influence of compaction effectiveness on interlayer bonding of asphalt layers. In: The 9th international conference "Environmental Engineering" (p. 7). 22-23 May 2014, Vilnius, Lithuania, 2014. D0I: 10.3846/enviro. 2014.158.

Kruntcheva, M.R., Collop, A.C. and Thom, N.H., (2005) Effect of bond condition on flexible pavement performance. Journal of Transportation Engineering, v.131, n.11, p. 880-888. DOI: 10.1061/(ASCE)0733-947X(2005)131:11(880)

Lopes, R. A. (2019) Avaliação de programas de retroanálise de bacias deflectométricas - aplicação a um trecho de uma rodovia federal. 263p. (Master's Thesis). Programa em Engenharia Civil, Universidade Federal do Rio de Janeiro - COPPE/UFRJ. Rio de Janeiro-RJ. Disponível em: < http://www.coc.ufrj.br/pt/dissertacoes-de-mestrado/617-msc-pt-2019/9308-rosilenealves-lopes-5> (acesso em 20/05/2020).

Mehta, Y. (2007) Evaluation of interlayer bonding in HMA pavements. Report No. 0092-02-13, WHRP 07-07, Wisconsin Department of Transportation, WI, USA.

Mousa, M., Elseifi, M.A., Elbagalati, O. and Mohammad, L.N. (2019) Evaluation of interface bonding conditions based on nondestructing testing deflection measurements. Road Materials and Pavement Design, v. 20, n.3, p. 554-571. DOI: 10.1080/14680629.2017.1400995.

Nascimento, L. A. H. (2015) Implementation and Validation of the Viscoelastic Continuum Damage Theory for Asphalt Mixture and Pavement Analysis in Brazil. 304f. (PhD disseration). North Carolina State University. Raleigh, NC.

Neumann, G. P. (2018). Um exemplo de dosagem de concreto asfáltico por meio da metodologia SUPERPAVE. 61f. Monografia (Undergraduate thesis). Universidade Federal de Juiz de Fora, Juiz de Fora/MG.

Nguyen, A. D. (2016) Nondestructive evaluation of bonding condition of asphalt pavement based on measured deformation of the road. In Transportation research board 95th annual meeting (No.16-0211) Washington DC, United States.

Santos, A.G., de Assis, R.K.M. and Fernandes Júnior, J.L. (2019) Efeito da aderência entre camadas na previsão de desempenho de pavimentos asfálticos. Revista Transportes, v. 27, n.2, p. 89-101. DOI: 10.14295/transportes. v27. i2.1597.

Scherer, R.G. (2018) Estudo da influência da condição de aderência entre camadas de pavimentos em seu comportamento mecânico. 170f. (Master's Thesis). Programa de Pós-Graduação em Engenharia Civil, Universidade Federal de Santa Maria. Santa Maria/RS. Disponível em: <https://repositorio.ufsm.br/handle/1/15839> (acesso em 15/05/2020).

Scherer, R. G. ; Bueno, L. D. ; Pereira, D. S. ; Specht, L. P. ; Nascimento, L. A. H. ; Fritzen, M. A. and Franco, F. A. C. P (2019) Influência da aderência entre camadas de pavimentos no dano à fadiga de revestimentos asfálticos. REVISTA ESTRADAS (PORTO ALEGRE), v. 24, p. 62-68.

Silva, R. C.; Motta, L. M. G.; Vianna, K. K. L.; Souza JR, J. G. and Costa, D. P. (2018) Levantamento Visual Contínuo Informatizado (LVCI) pelo Método da Varredura - Comparação com outros Métodos. REVISTA ESTRADAS (PORTO ALEGRE), v. 23, p. 64-70.

Romanoschi, S.A. and Metcalf, J.B. (2001) Effects of interface condition and horizontal wheel loads on the life of flexible pavement structures. Transportation Research Record, v.1778, n1, p. 123-131. DOI: 10.3141/1778-15

Torquato e Silva, S. A., Souza, W.A.R and Soares J.B. (2019) Método simplificado para a consideração da aderência entre camadas no dimensionamento de pavimentos asfálticos. Anais do 33ํㅡㄹ Congresso de Pesquisa e Ensino em Transportes, ANPET, Balneário Camboriú, v.1, p. 1547-1556.

Uzan, J., Livneh, M. and Eshed, Y. (1978) Investigation of adhesion properties between asphaltic-concrete layers. In Association of Asphalt Paving Technologists Proc. v.47, p. 495-521. 